\title{
The Environmental Rules of Economic Development: Governing Air Pollution from Smelters in Chuquicamata and La Oroya
}

\author{
JOSÉ CARLOS ORIHUELA*
}

Abstract. Why and how do societies transform the environmental rules of economic development, or fail to do so? This article compares the experiences of Chile and Peru in the regulation of smelting activities between 1990 and 2010. Air pollution from smelters in Chuquicamata and La Oroya, each emblematic of the two countries' mining industries, did not give rise to nationally destabilising protest. Nevertheless, despite the absence of pressing discontent with pollution, the environmental rules for mining could still be improved as a result of policy network activism and through highly idiosyncratic institutional channels. The analysis shows that policy entrepreneurship for Chuquicamata was enhanced by a national institutional environment that favoured bureaucratic autonomy, while parallel action for La Oroya was constrained by a political economy of state weakness and elite disregard.

Keywords: Chile, Peru, environment, development, mining, institutions, policy entrepreneurs

\section{Introduction}

Chuquicamata and La Oroya were the first industrial-scale mining ventures in Chile and Peru respectively, and became critical nodes for the national political economy of development processes, from the rise of labour in the first quarter of the twentieth century to the advent of varieties of

José Carlos Orihuela is associate professor in the Economics Department at the Pontificia Universidad Católica del Perú. Email: orihuela.jc@pucp.edu.pe.

* I wish to express my gratitude to the Institute of Latin American Studies at Columbia University and the CICR Fund for Global Environment and Conflict Resolution Fellowship for funding research on this project, and to all interviewees for sharing their policy histories. I am tremendously grateful to John Coatsworth and Rosemary Thorp for guidance along the way, as well as to Ira Katznelson, José Antonio Ocampo, Maritza Paredes and the JLAS referees and editors, for their comments and criticisms. Last but not least, I thank Anthony Bebbington and Cynthia Sanborn, who commented and provided the first venue for my work in progress at LASA 2009. 
Latin American neoliberalism in the last. ${ }^{1}$ Prior to the early I990s, when national environmental commissions were established (the Comision Nacional del Medio Ambiente, CONAMA, in Chile, and the Consejo Nacional del Ambiente, CONAM, in Peru) and national environmental laws were passed, no environmental authority regulated mining industries in either country. Macro-legal reform, however, did not produce similar environmental rules for mining industries. In Chile, Chuquicamata's owner, the Corporación Nacional del Cobre (National Copper Corporation, CODELCO), was pressured to cut its emission of pollutants drastically, and did so; in Peru, Doe Run, La Oroya's owner, was treated leniently by regulators and ultimately failed to reach global air quality standards. This article explains why and how environmental regulation of smelters in Chile and Peru followed different pathways.

The absence of social unrest in Chuquicamata and its limited political significance in La Oroya leads the analysis to focus on the functioning of state apparatuses. Unlike many contemporary mega-projects in the Andes or Latin America more broadly, in Chuquicamata and La Oroya there has been little sign of destabilising protest against the environmental consequences of development (actual or expected). ${ }^{2}$ Of the pair, the less clear-cut case is La Oroya. There has been plenty of environmental activism in La Oroya, but arguably this has not had a high political impact on Lima power circles. ${ }^{3}$

${ }^{1}$ For an introduction to long-term trajectories and broad significance, see, on Chuquicamata, Janet Finn, Tracing the Veins: Of Copper, Culture, and Community from Butte to Chuquicamata (Berkeley, CA: University of California Press, 1998); Simon Collier and William Sater, A History of Chile, 1808-2002 (New York: Cambridge University Press, 2004); and Augusto Millán, La minería metálica en Chile en el siglo XX (Santiago: Editorial Universitaria, 2006); and, on La Oroya, Adrian W. DeWind, 'Peasants Become Miners: The Evolution of Industrial Mining Systems in Peru', unpubl. PhD diss., Columbia University, 1977; Rosemary Thorp and Geoffrey Bertram, Peru, 1890-1977: Growth and Policy in an Open Economy (New York: Columbia University Press, 1978); and David Becker, The New Bourgeoisie and the Limits of Dependency: Mining, Class, and Power in 'Revolutionary' Peru (Princeton, NJ: Princeton University Press, 1983).

${ }^{2}$ On mining protest, see, for instance, Anthony Bebbington et al., 'Mining and Social Movements: Struggles over Livelihood and Rural Territorial Development in the Andes', World Development, 36: I 2 (2008), pp. 2888-905; Kathryn Hochstetler, 'The Politics of Environmental Licensing: Energy Projects of the Past and Future in Brazil', Studies in Comparative International Development, 46: 4 (20 I I), pp. 349-7 I; and Anthony Bebbington (ed.), Social Conflict, Economic Development and the Extractive Industry: Evidence from South America (London: Routledge, 20 I 2).

3 The most influential contentious activism related to mining has taken place in Piura, Cajamarca, Ancash, Arequipa and Cusco: see Anthony Bebbington (ed.), Minería, movimientos sociales y respuestas campesinas; una ecología politica de las transformaciones territoriales (Lima: IEP and CEPES, 2007); Defensoría del Pueblo, 'Informe extraordinario: los conflictos socioambientales por actividades extractivas en el Perú, I 6 April 2007', available at http://cies.org.pe/proyecto-fortalecimiento-de-capacidades/matriz-bibliografica/Informeextraordinario; José de Echave et al., Minería y conflicto social (Lima: IEP, CIPCA, CBC and 
In fact, mobilisation in both La Oroya and Lima has also taken place in support of the polluting company, led by the labour unions and overshadowing local environmentalism. The long presence of mining and downstream activities in these sites and the high levels of employment generated, compared with purely extractive projects and neighbouring economic activities, explains the apparent wider acceptance of pollution by local people.

Why and how, then, do environmental conditions at a local, even remote site become a national priority when those bearing the brunt of their impact do not make enough noise? By answering this question, this comparative study aims to contribute to a better understanding of the processes of policy-making and institutional change. I will do this by explaining first the general argument of how to move away from a 'bad governance' status quo, presenting arguments about the role and significance of policy agency, institutional legacy and political economy opportunity. The paper then introduces the cases of the mining towns of Chuquicamata and La Oroya, describing old environmental problems and new opportunity structures for policy action. Finally, the article assesses the development of policy entrepreneurship, showing how each country's domestic political economy offered social environments which enhanced or constrained policy agency for both Chuquicamata and La Oroya. The practical relevance of the comparative analysis goes well beyond the industry and locations that make up the stage for the action. Over the last two decades, the national economic development versus environmental protection debate has gained salience across Latin America, reshaping economics, politics and societies. ${ }^{4}$

\section{Moving Away from Lenient Regulation}

There are many factors that can explain an enduring policy equilibrium with negative consequences, from powerful economic interests to failing policy culture. The political economy of pollution from smelters offers its own set of 'resistance to change' features: environmentalism is likely to face a hostile

CIES, 2009); Martin Scurrah (ed.), Defendiendo derechos y promoviendo cambios: el estado, las empresas extractivas, y las comunidades locales en el Perú (Lima: Oxfam Internacional, IBC and IEP, 2008); and Javier Arellano, ¿Mineria sin fronteras? Conflicto y desarrollo en regiones mineras del Perú (Lima: PUCP, UARM and IEP, $20 \mathrm{r}$ ).

${ }^{4}$ See, for example, the conflicts over the Belo Monte dam in Brazil: Hochstetler, 'The Politics of Environmental Licensing'; Georgia O. Carvalho, 'Environmental Resistance and the Politics of Energy Development in the Brazilian Amazon', Journal of Environment and Development, I 5: 3 (2006), pp. 245-68; Sabrina McCormick, 'Damming the Amazon: Local Movements and Transnational Struggles over Water', Society and Natural Resources, 24: I (201 I), pp. 34-48; Anthony Hall and Sue Branford, 'Development, Dams and Dilma: The Saga of Belo Monte', Critical Sociology, 38: 6 (2012), pp. 85 I-62. 


\section{54 José Carlos Oribuela}

grassroots arena. Smelters create jobs that purely extractive mineral activities cannot match. This characteristic means that the people directly affected by contamination are commonly those directly benefited by the polluting industry. In addition to the challenge of a stylised problem of collective action to organise protest or to construct governance, the dependence on mining income, or the expectations of seizing part of it, makes the political economy of governing air pollution from smelters a highly complex social phenomenon.5 Contentious collective action like raising environmental banners in old mining towns is unlikely to be as vigorous as that taking place in agricultural or stock-farming towns facing new mining prospects. For example, environmental politics in sites like La Oroya or Chuquicamata differ from those of sites like Conga or Pelambres. ${ }^{6}$ Pollution can be welcomed, even vociferously defended, as in La Oroya, by a critical mass of citizens, for some time at least, as the price of economic development. ${ }^{7}$ In principle, it becomes easier for mining companies and government officials to turn a blind eye to the possibility and dimension of negative externalities in such sites. Given the high dependence on mining, environmental regulatory leniency can be defended in the name of local jobs and the overall development of the national economy.

How, then, can long-enduring policy failure be reversed? Unless a critical event, such as an 'environmental emergency', takes place and helps to alter beliefs, preferences and the overall structure of opportunities for (contentious) collective action, environmental change in sites like La Oroya and Chuquicamata is more dependent on formal institutional mechanisms and, therefore, the initiative of political elites and government officials. ${ }^{8}$ Thus, the

s On collective action, see Mancur Olson, The Logic of Collective Action: Public Goods and the Theory of Groups (Cambridge, MA: Harvard University Press, 1965); Russell Hardin, Collective Action (Baltimore, MD: Johns Hopkins University Press, 1982); Elinor Ostrom, Governing the Commons: The Evolution of Institutions for Collective Action (New York: Cambridge University Press, 1990); and Sydney Tarrow, Power in Movement: Social Movements and Contentious Politics (New York: Cambridge University Press, 1998).

${ }^{6}$ On mining and conflict, see the works cited in note 3 for Peru and, for the Chilean case, César Padilla and Pablo San Martín, Conflictos ambientales: una oportunidad para la democracia (Santiago: OLCA and IEP, I990); and Pablo San Martín, Conflictos ambientales en Chile (Santiago: OLCA and IEP, 1997). Book production reflects the weight of socioenvironmental conflict associated with mining in domestic polities.

7 A telling counter-example is provided by Ilo, on the Peruvian side of the Atacama Desert, which produced a marked environmentalist social movement in the 1980 s. Yet mining in Ilo is not as old as it is in La Oroya, and its hosting economic geography is not as extreme as that of Chuquicamata, where mining is virtually the only activity. There is more on the Ilo case below.

${ }^{8}$ Drawing on Doug McAdam, John McCarthy and Mayer Zald (eds.), Comparative Perspectives on Social Movements: Political Opportunities, Mobilizing Structures and Cultural Framings (Cambridge: Cambridge University Press: 1996); and Tarrow, Power in Movement. By 'environmental emergency', I refer to an environmental event with consequences that are perceived as 'new' and 'pressing' by a community. Citizens in mining 
argument on how to escape a policy trap in cases like those that concern us here builds on three elements: policy agency, institutional legacy and political economy opportunity. 9 The first contention is that entrepreneurial policy agency is the heart of institutional change. In a social context of widespread disregard for environmental well-being, policy entrepreneurs aiming to impose or to persuade those in power about the need for new state action become critical. However, although it is a necessary ingredient, policy entrepreneurship is not sufficient. The 'enlightenment' of bureaucrats per se does not determine public choice. To understand how and why the private preferences of a handful of environmentally minded officials become statecraft, one needs to read the political economy of policy-making in a historical perspective that embraces complexity and contingency, rather than as an oversimplified game of 'rational choice' players. ${ }^{10}$

This leads to the second contention of the general argument, which is that the institutional legacy matters for policy agency. It is expected that enduring social constructions will shape the preferences and belief systems of policy-makers. The assertion brings to the fore insights from sociological institutionalism on the cognitive function of institutions. ${ }^{\text {I }}$ The way policymakers learn constitutes a fundamental micro-level foundation for the macrolevel observation of state behaviour. Some institutional legacies of state and society could then provide resources for state actors attempting to move away from a negative policy or institutional equilibrium: the structure could help change the structure, regardless of how aware revolutionary or reformist agents

towns can grow used to living with pollution and therefore do not perceive, for example, that many children with respiratory and skin problems and a few children with development problems and who eventually suffer premature death constitute an emergency. However, a radical switch from that baseline, or the perception of it, might create an 'environmental emergency'.

9 With a focus on policy elite networks, I use the framework depicted below to analyse macro-economic policy-making in José Carlos Orihuela, 'How do "Mineral-States" Learn? Path-Dependence, Networks and Policy Change in the Development of Economic Institutions', World Development, 43: 3 (2013), pp. 138-48.

10 'History matters' arguments of this kind across the social sciences include Albert Hirschman, Journeys toward Progress: Studies of Economic Policy-Making in Latin America (New York: Twentieth Century Fund, 1963); Charles Tilly, 'To Explain Political Processes', American Journal of Sociology, гоo: 6 (1995), pp. I 594-6 1 o; Karla Hoff and Joseph Stiglitz, 'Modern Economic Theory and Development', in Gerald Meir and Joseph Stiglitz (eds.), Frontiers of Development Economics: The Future in Perspective (New York: Oxford University Press, 200I), pp. 389-478; and Paul Pierson, Politics in Time: History, Institutions and Social Analysis (Princeton, NJ: Princeton University Press, 2004).

I See Walter Powell and Paul DiMaggio, The New Institutionalism in Organizational Analysis (Chicago, IL: University of Chicago Press, 1991); and Richard Scott, 'Approaching Adulthood: The Maturing of Institutional Theory', Theory and Society, 37: 5 (2008), pp. $427-42$. 


\section{56 José Carlos Oribuela}

are of the matter. In contrast, a poor institutional endowment can seriously limit the choices of reformist policy-makers, since institutional capacities and traditions would not offer a mental map as a guide to a solution.

The third contention is that political economy opportunity is central in the making of a chain of policy events leading to enduring institutional change. In both informal and formal development arenas, agency takes place within shifting opportunity structures. ${ }^{12}$ Some of those structural opportunities and constraints are the result of historical legacies; others are associated with contemporary local, national and global processes and extraordinary events. A fundamental contribution of the new historical institutionalism is to show the centrality of time for the formation and evolution of institutions: institutional change is highly dependent on the sequencing of inputs and the feedback effects of contingent processes. ${ }^{13}$ The opening of windows of opportunity, a critical juncture, facilitates the efforts of reformers; yet, institutional change is generally characterised by piecemeal evolution. ${ }^{14}$

Summing up, the political economy of development observed for smelters and the framework depicted for analysing policy-making and institutional change leads us to focus on the agency of key state actors, and to inquire about the role played in it by legacy and opportunity, in order to understand the development of new institutions for better governance of mining. Public choice is the result of a complex game in which empowered actors agree on what is better for 'the greater public good'. Accordingly, for smelter pollution to diminish, in the absence of a destabilising form of social unrest and given a shifting structure of opportunity, policy entrepreneurs needed to succeed in constructing a coalition for change within the high ranks of public decision-makers. We move next to examine how and indeed whether that in fact happened.

\section{Old Problems, New Opportunities}

Chile and Peru are middle-income countries with a traditionally high dependence on mineral resources. Over the last century the mining industry as

${ }^{12}$ For instance, see Tarrow, Power in Movement; and Ira Katznelson, 'Periodization and Preferences: Reflections on Purposive Action in Comparative Historical Social Science', in James Mahoney and Dietrich Rueschemeyer (eds.), Comparative Historical Analysis in the Social Sciences (New York: Cambridge University Press, 2003), pp. 270-304.

${ }^{13}$ See Kathleen Thelen, 'Historical Institutionalism in Comparative Politics', Annual Review of Political Science, 2 (1999), pp. 369-404; and 'How Institutions Evolve: Insights from Comparative Historical Analysis', in Mahoney and Rueschemeyer (eds.), Comparative Historical Analysis in the Social Sciences, pp. 208-40; and Pierson, Politics in Time.

${ }^{14}$ On the former, see David Collier and Ruth Berins Collier, Shaping the Political Arena: Critical Junctures, the Labor Movement, and Regime Dynamics in Latin America (Princeton, NJ: Princeton University Press, I99 I); on the latter, see note I 2 above. 
a whole has varied in importance, representing between 45 and 90 per cent of exports in Chile for most of the period and between 30 and 70 per cent of exports in Peru (the latter figures include hydrocarbons). During the last decade mining was in the range of $65-70$ per cent of exports and 20-25 per cent of the fiscal revenue of both countries. Resource-based development has produced significant environmental by-products. Peruvian authorities have given rough estimates for the remedial costs of abandoned 'environmental legacies' (pasivos ambientales) in the range of US\$250-800 million. ${ }^{15}$ The government of Peru identified 850 environmental legacies in 2008, but the figure had risen to 6,847 by $20 \mathrm{II}^{\mathrm{I}}{ }^{16}$ Chile only registers about 3 per cent of the updated number. ${ }^{17}$ Similarly, in Peru, remediation plans for privatised companies amount to some US\$ 700 million, while in Chile state-owned CODELCO estimated remediation costs at US\$ 300 million. ${ }^{18}$ These estimates are based on partial evaluations, but for both abandoned and state-owned waste they all point to much larger environmental failures and challenges north of Arica. However, after more than a decade of environmental reforms and mining-led growth, successive governments of Peru did little more than establish a modest US\$ 20 million remediation trust fund for abandoned legacies, while the Chilean government invested more than US\$ 1.5 billion just in reducing air pollution from smelters. ${ }^{19}$

Chuquicamata and La Oroya are at the heart of this story. Their first industrial-scale smelting facilities were opened in I9I5 and 1922 respectively. Their geographical locations - Chuquicamata in the Atacama Desert and La Oroya in Peru's central Andes - illustrate the contrasting environmental challenges most mining activities have faced in these countries. In Chile, modern mining developed in areas of low population density, while in Peru, it developed in relatively highly populated and poor parts of the country. With respect to air pollution, the Atacama minerals are rich in arsenic, while those of the central Andes of Peru offer a higher complexity of metals and the

is See Ministerio de Energía y Minas, 'Inventario de pasivos ambientales mineros, proyecto de eliminación de pasivos ambientales', Dec. 2003; and World Bank, Riqueza y sostenibilidad: dimensiones sociales y ambientales de la minería en el Perú (World Bank, Unidad de Gestión del País-Perú, 2005).

${ }^{16}$ See Ministerio de Energía y Minas, 'Pasivos ambientales', Memo 885-2008-MEM-AMM, Lima, 2008; and José Balta, 'Los 6.847 pasivos ambientales de la minería', available at www. infos.pe/20 I I / I / cuando-la-mineria-se-acaba-6847-pasivos-ambientales.

${ }^{17}$ Krugger Montalbán, 'PAM en Chile', in 2 da Conferencia Internacional de Pasivos Ambientales Mineros PAM (Santiago: CEPAL, 2005).

${ }^{18}$ See Ministerio de Energía y Minas, 'Opinión del Perú sobre el informe final de la revisión de las industrias extractivas al Banco Mundial', Feb. 2004; and Juan Villarzú, 'CODELCO y su aporte al desarrollo sustentable', Revista Ambiente y Desarrollo, i 8 (2002), pp. 76-8.

19 See Ministerio de Energía y Minas, 'Respuesta a la interpelación del Congreso', Lima, Nov. 2006; and COCHILCO, 'Análisis de inversiones ambientales en las fundiciones estatales de cobre’, Inscripción no. I 38.493, ISBN 956-8242-02-3, 2003. 


\section{Table I. The Chuquicamata and La Oroya Smelters}

\begin{tabular}{|c|c|c|}
\hline & Chuquicamata & La Oroya \\
\hline Location & $\begin{array}{l}\text { Atacama Desert, 2,800 metres } \\
\text { above sea level }\end{array}$ & $\begin{array}{l}\text { Central Andes of Peru, 3,700 } \\
\text { metres above sea level }\end{array}$ \\
\hline Starting date & 1915 & 1922 \\
\hline Main pollutants & rsenic, sulphur dioxide & $\begin{array}{l}\text { Lead, sulphur dioxide, cadmium, } \\
\text { arsenic }\end{array}$ \\
\hline Industrial setting & $\begin{array}{l}\text { Processes minerals from } \\
\text { Chuquicamata, world's largest } \\
\text { open-pit mine }\end{array}$ & $\begin{array}{l}\text { Processes minerals from all over } \\
\text { the Central Andes, including the } \\
\text { Cobriza mine }\end{array}$ \\
\hline Technology, c. 1990 & $\begin{array}{l}\text { Reverberatory/Teniente } \\
\text { converter/flash }\end{array}$ & Reverberatory \\
\hline $\begin{array}{l}\text { Current productive } \\
\text { capacity }\end{array}$ & 500,000 metric tons of copper & $\begin{array}{l}\text { 80,000 metric tons of copper, } \\
\text { I 40,000 metric tons of lead and } \\
\text { 50,000 metric tons of zinc }\end{array}$ \\
\hline Ownership & $\begin{array}{l}\text { Nationalised in 1970, part of } \\
\text { state-owned CODELCO since } \\
\text { 1976 }\end{array}$ & $\begin{array}{l}\text { Nationalised in 1974, became part } \\
\text { of CENTROMIN; bought by } \\
\text { Doe Run (part of the Renco } \\
\text { Group) in } 1997\end{array}$ \\
\hline $\begin{array}{l}\text { Environmental } \\
\text { controversies }\end{array}$ & $\begin{array}{l}\text { Small indigenous communities } \\
\text { live in the highlands and use the } \\
\text { scarce water sources for cattle } \\
\text { and subsistence farming. } \\
\text { - Presence of arsenic in air, water } \\
\text { and consumed food is higher } \\
\text { in northern Chile than elsewhere } \\
\text { in the country. Prevalence of } \\
\text { cancer associated with drinking } \\
\text { water. }\end{array}$ & $\begin{array}{l}\text { - } 65 \text { documented cases of high } \\
\text { threats to life litigated by the } \\
\text { Inter-American Court of } \\
\text { Human Rights. } \\
\text { - Virtually roo\% of children with } \\
\text { blood-lead levels above WHO } \\
\text { and USEPA precautionary } \\
\text { thresholds. } \\
\text { - Air, water and soil pollution in } \\
\text { the Mantaro valley. }\end{array}$ \\
\hline $\begin{array}{l}\text { Potentially directly } \\
\text { impacted } \\
\text { population }\end{array}$ & $\begin{array}{l}\text { In } 2006, \text { CODELCO closed } \\
\text { the mining town of i } 5,000 \\
\text { inhabitants ( } 8,000 \text { of whom } \\
\text { were children) and relocated } \\
\text { people to Calama, a city of } \\
\text { I } 25,000 \text { inhabitants. }\end{array}$ & $\begin{array}{l}\text { In } 2007,20,000 \text { people lived in } \\
\text { the district of La Oroya ( } 6,000 \text { of } \\
\text { whom were children), part of the } \\
\text { population of } 50,000 \text { in the Yauli } \\
\text { province. Some } 600,000 \text { people } \\
\text { live in the Mantaro valley. }\end{array}$ \\
\hline
\end{tabular}

Source: drafted by author using data from DIGESA, CDC, CONAMA, ESAN and USGS.

presence of lead (see also Table I). In addition, Chuquicamata has the natural advantage of a wind that blows generally in an easterly direction, over the desert. In contrast, the city of La Oroya developed virtually adjacent to the metallurgical complex, which is surrounded by mountains in the upper reaches of the important Mantaro River basin. Hence mining in the central Andes of Peru developed next to the Mantaro Valley's agricultural activities, contributing to the dynamism of the local economy as well as impacting on environmental conditions, as discussed below.

By 1990 , the problem of pollution generated by CODELCO in Chuquicamata was more the concern of environmental scientists and professionals than of unions or the local population in the mining town 
of Chuquicamata and the city of Calama, some 16 kilometres away. It is important to qualify this general picture, however. First, there is an old grievance from small upstream indigenous groups that need the scarce water supplies. ${ }^{20}$ Second, there are high levels of arsenic in the potable water in Calama and the whole Antofagasta region. ${ }^{21}$ In this context, drastic climatic events altering rain patterns create threats and fears. For instance, in 1997 heavy rains flooded the Loa River, resulting in massive deaths of fish. ${ }^{22}$ Calama citizens blamed Chuquicamata's Sloman dam for the pollution. A United Nations mission concluded that it could not determine the sources of the pollution and that authorities should develop an environmental monitoring programme for the Loa River. ${ }^{23}$ Industrial activities alter the natural behaviour of ecosystems, yet the complexity of the earth and water systems makes it difficult to determine the contribution of mining to the observable phenomenon of water systems that are rich in metals. However, the effect of mining on air pollution is more evident, since 'natural air pollution' is not significant and there is no other industrial activity in the area.

Unlike Chuquicamata, La Oroya has always been a pollution 'hot spot'. In 1922 the opening of the smelter ('without what would be classified in any form as smoke control') created the first notorious case of industrial pollution. ${ }^{24}$ It led to action by affected large landowners (hacendados) and indigenous communities, resulting in government commissions that mandated a remediation settlement. The Cerro de Pasco Corporation had to buy the polluted land, which eventually recovered from the pollution decades later. Cerro finally developed a cattle division on the terrain it had acquired and became the largest landowner in the Andes by the late $1960 .^{25}$

${ }^{20}$ Gustavo Lagos et al., 'Minería, minerales y desarrollo sustentable en Chile', in Equipo MMSD América del Sur, Minería, minerales y desarrollo sustentable en América del Sur (Geneva: CIPMA, IDRC and IIPM, 2002), pp. 341-440.

${ }^{21}$ Ana María Sancha, 'Case Study: Arsenic Pollution in the North of Chile and its Impact in the Ecosystem and Human Health', IDRC, 2000, available at http://web.idrc.ca/rpe/ev83 I 80-20I-I-DO_TOPIC.html; Dirección General de Aguas, 'Diagnóstico y clasificación de los cursos y cuerpos de agua según objetivos de calidad: informe final, 2004', available at http://documentos.dga.cl/CQA4432vi.pdf.

22 'Large amounts of foam were visible all the way from Calama to the Pacific and brownish water was observed as well', the Joint UNEP/OCHA Environment Unit mission reported: see UNEP/OCHA, 'UN Expert Assessment Mission in Connection with Acute Pollution of the Loa River', July 1997, found at www.reliefweb.int/ocha_ol/programs/response/unep/ chilerep.html (last accessed ıo Dec. 20 10, no longer available).

${ }^{23} \mathrm{Ibid}$. See also Dirección General de Aguas, 'Diagnóstico y clasificación de los cursos y cuerpos de agua según objetivos de cualidad: Cuenca Río Loa, 2004', available at www.sinia.cl/r292/ articles-3 I I I 8_Loa.pdf.

${ }^{24}$ Quote from DeWind, 'Peasants Become Miners', p. 55.

${ }^{25}$ Ibid. See also Becker, The New Bourgeoisie; Elizabeth Dore, The Peruvian Mining Industry: Growth, Stagnation and Crisis (Boulder, CO: Westview Press, 1988); and Alberto Flores Galindo, Los mineros de Cerro de Pasco, I9oo-1930 (Lima: SUR, 1993). 
Eight decades after the case of 'the fumes', international environmental activists listed La Oroya among the ten most polluted places in the world. ${ }^{26}$ Given the controversy, the US Agency for International Development (La Oroya had been sold to a US-based company, Doe Run Resources, when it was privatised in 1997) requested the US Centers for Disease Control and Prevention (CDC) to provide a technical opinion regarding public health and the regulatory system. Peruvian Ministry of Health agencies and civil society organisations had carried out a number of studies pointing to severe threats to health and life. ${ }^{27}$ The CDC found that all available surveys showed excessive levels of lead in the blood of affected populations, and concluded that the environmental health infrastructure needed to oversee air, water and soil was 'seriously underdeveloped': no emission control was in place at the lead processing plant, and soil contamination had not been studied. ${ }^{28}$ Table I summarises the central environmental and industrial features. Prior to 1990, no regulation existed over air pollution from the mining industry in either country. National air quality standards had been established by the Chilean Ministry of Health in 1978 , but no authority had enforced them during their first decade of existence.

From afar, it seems clear that by the early I 990 s there was no alternative for mineral-rich Chile and Peru but 'green mining', at least in forms and discourse. Despite the degree of environmental awareness among state officials by then, mega-project industries had already been forced to carry out environmentalist re-engineering by changes in the global political economy. ${ }^{29}$ As a sign of the times, the United Nations Conference on Environment and Development, the 'Earth Summit', was to take place in Rio de Janeiro in 1992. In the early 1990 s foreign mining corporations and financial institutions (the World Bank's equity investment entity, the International Finance

${ }^{26}$ Blacksmith Institute, 'The 2006 Top Ten of The World's Worst Polluted Places', available at www.blacksmithinstitute.org/the-2006-top-ten-of-worst-polluted-places.html.

27 See DIGESA, 'Estudio de plomo en sangre en una población seleccionada de La Oroya', Lima, 1999; Anna Cederstav and Alberto Barandarian, La Oroya Cannot Wait (Lima: SPDA and AIDA, 2002); Ramón Pajuelo, Medio ambiente y salud en La Oroya: sistematización de un programa de intervención (Lima: CooperAcción, 2005); and Universidad de San Luis and Arzobispado de Huancayo, 'Estudio sobre la contaminación ambiental en los hogares de La Oroya y Concepción y sus efectos en la salud de los residentes', Lima, 2005, available at www. aida-americas.org/en/node/1 735 .

28 The CDC study stated that no public health action would work unless emissions were curbed and recommended a 'scientifically robust plan' to monitor the impact of efforts at emission reduction: see CDC, 'Development of an Integrated Intervention Plan to Reduce Exposure to Lead and Other Contaminants in the Mining Center of La Oroya, Peru', 2005, pp. I 2-I3, available at www.cdc.gov/nceh/ehs/Docs/la_oroya_report.pdf.

29 See, for instance, John McCormick, Reclaiming Paradise: The Global Environmental Movement (Bloomington, IN: Indiana University Press, 1989); and Sanjeev Khagram, Dams and Development: Transnational Struggles for Water and Power (Ithaca, NY: Cornell University Press, 2004). 
Corporation, was a minority partner in a number of new ventures) actually solicited the Chilean and Peruvian authorities to establish basic environmental rules in order to close investment deals. ${ }^{30}$

Before Rio 1992, elite and social movement activism had introduced the environmental question into the politics of development in both Chile and Peru. By the I 980 os mining was broadly perceived by domestic experts as perhaps the dirtiest of all national industries. ${ }^{31}$ In Chile, in the 1980 , a diffuse coalition for change was in the making in professional societies and policy circles, since both formal and grassroots politics were banned. Under the Pinochet dictatorship (1973-90), cases of mining pollution were taken to the courts for the first time. The 1980 Constitution had granted Chilean nationals 'the right to live in an unpolluted environment'. Hence a handful of litigating environmental lawyers became star actors in the push for greening Chile, including Rafael Asenjo, who would move from society to state at the return to democracy. In I98 I, a first case of mining pollution came to the courts. The case against the state-owned Empresa Nacional de Mineria (National Mining Enterprise, ENAMI), alleging air pollution from the Ventanas copper smelter, was dismissed. A second case had a better outcome. In 1988 the Supreme Court upheld a previous rule ordering the state-owned copper giant, CODELCO, to stop dumping mine tailings in the Salado River and hence affecting the bay of Chañaral, a practice that had persisted for six decades. ${ }^{32}$ Not only were environmental lawyers developing jurisprudence, but mining pollution was gaining space in the national press, and concerned scientists were raising their voices to persuade policy-makers about the critical condition of air contamination from smelters. ${ }^{33}$ Finally, a contingent process, the worsening of air pollution in Santiago throughout the decade, had generated a larger audience for the advocates of environmental reform.

The environmental question had also been raised in Peru in the r980s. The process there, however, stands in sharp contrast to that of Chile. In the I 970s, with a military government (albeit a reformist one until I975), oil crises and increasingly mobilised social movements, the long-standing grievance

${ }^{30}$ Interviews with Jaime Solari, chief of the environmental unit of the Ministry of Mining between 1990 and 1994, Santiago, 24 Aug. 2007, and César Polo, an important collaborator of President Fujimori's first mining and energy minister, Fernando Sánchez Albavera, Lima, 3 Apr. 2008.

${ }^{31}$ See ONERN, Perfil ambiental del Perú (Lima: ONERN and USAID, i 986); and Gustavo Lagos, 'Un análisis de la situación del medio ambiente en relación con la minería chilena', Serie Documentos de Seminario - Sector Minero (Santiago: CIPMA, 1990).

${ }^{32}$ Rafael Asenjo, 'Innovative Environmental Litigation in Chile: The Case of Chañaral', Georgetown International Environmental Law Review, 2: 99 (1989), pp. 99- I 10.

33 See Gustavo Lagos and Patricio Velasco, 'Environmental Policies and Practices in Chilean Mining', in Alyson Warhurst (ed.), Mining and the Environment: Case Studies from the Americas (Ottawa: IDRC, 1999), pp. I01-36. 
of the provinces against the capital city developed new forms of expression of social unrest. Regional and local defence fronts spread, demanding greater political autonomy for the provinces and a better share of resource rents, the canon, such as those from oil and mining. ${ }^{34}$ Particularly important was the Frente de Defensa de los Intereses de Ilo (Front for the Defence of the Interests of Ilo), created in the context of contentious collective action against the Southern Peru Copper Corporation, the largest foreign investor in the domestic economy at that time.35 The 1979 Constitution gave the canon scheme, the principle of redistributing resource rents between the central state and the producing region, a constitutional status. It also declared environmental well-being to be a constitutional right. Years later, the Ilo social movement found the environmental problems associated with mining and air pollution, as well as water pollution and scarcity, to be effective for identity-building and mobilisation. ${ }^{36}$ Especially after the mid-1980s, the Ilo struggle generated political momentum for the efforts of legislators to pass environmental reforms, although they were not successful until the end of the decade. ${ }^{37}$ In fact, the movement's leader, Julio Díaz Palacios, mayor of the city of Ilo throughout the $1980 \mathrm{os}$, became a congressman and was instrumental in the approval of the short-lived National Code of the Environment and Natural Resources in 1990. By the end of the 1980s, Peruvian politics were dominated by hyperinflation and the political violence of Sendero Luminoso (Shining Path) and its repression, incubating forces for the decade-long authoritarian government under Alberto Fujimori.

After the groundwork carried out by national civil societies for more than a decade, the year 1990 brought opportunity for environmental reform of two very different kinds. In Chile, democracy returned and the Concertación, a left-of-centre coalition, emerged triumphant. Environmentally conscious technocrats filled influential advisory positions in the Ministerio Secretaría General de la Presidencia (Ministry of the General Secretary of the Presidency, SEGPRES), a portfolio with a mandate of political coordination, led by an environmentalist lawyer, Rafael Asenjo. Most importantly, the policy culture had been moving away from radical market fundamentalism, although still

34 See Martha Rodríguez, El Frente de Defensa del Pueblo de Loreto: ensayo de interpretación de un movimiento social (Lima: PUCP, Taller de Estudios Urbano Industriales, 1981); and Narda Henríquez, 'Notas y tesis sobre los movimientos regionales en el Perú', in Eduardo Ballón (ed.), Movimientos sociales y crisis: el caso peruano (Lima: DESCO, 1986), pp. $165-224$.

35 See Thorp and Bertram, Peru, I890-1977; and Fernando Sánchez Albavera, Minería, capital transnacional y poder en el Perú (Lima: DESCO, 1981).

${ }^{36}$ Doris Balvín, Agua, minería y contaminación: el caso Southern Perú (Ilo: LABOR, 1995).

37 Manuel Pulgar-Vidal and Isabel Calle, Para hacer tortillas hay que romper huevos: historia de la gestión ambiental en el Perú 19go-2005 (Lima: Sociedad Peruana de Derecho Ambiental, 2006). 
stressing macro-economic conservatism and the need for trade integration, the latter useful to the advancement of an environmentalist rationale for state action. ${ }^{38}$ The return to democracy under a progressive alliance created a critical juncture that favoured comprehensive environmental reform. During its first days in office the new administration announced that the decontamination of air in the capital, Santiago, was a priority and established a commission tasked with addressing the issue. It also created a second commission to draft comprehensive environmental reform, and Congress approved the national environmental law four years later. ${ }^{39}$

Opportunity for environmental reform of mining meant something else in Peru, which went headfirst into a version of free-market fundamentalism sceptical of any kind of government intervention. The 1990 Código del Medio Ambiente y Recursos Nacionales (Code of the Environment and Natural Resources), which established the principle of a national environmental authority, was modified in I99 I by critical legislation aiming to promote big (foreign direct) investment. ${ }^{\circ}$ Nevertheless, international development institutions had adopted environmental policy, which re-drew the structure of opportunity for state environmentalism. Among other far-reaching changes, structural adjustment reforms included the privatisation of the hydrocarbons and mining sectors. The process was accompanied by programmes that aimed to modernise the Ministry of Energy and Mining, amongst other selected government agencies. The effort included the establishment of environmental regulation of mining, which was previously non-existent.4r World Bank officials pushed for regulations and regulators that otherwise would have taken longer to materialise. In the context of across-the-board liberalisation, environmental regulation of mining in general and smelters in particular was brought in through World Bank conditionality.

\section{Enhanced Policy Entrepreneurs in Chile}

In Chile, the process of institutional change that drove the reduction of air pollution from smelters grew and developed from within national

${ }^{38}$ Patricio Silva, 'Technocrats and Politics in Chile: From the Chicago Boys to the CIEPLAN Monks', Journal of Latin American Studies, 23: 2 (1991), pp. 385-41 o; and Marcus Kurtz, 'Chile's Neo-Liberal Revolution: Incremental Decisions and Structural Transformation, 1973-89', Journal of Latin American Studies, 3 1: 2 (1999), pp. 399-427.

39 Juan Escudero and Joaquín Vial, 'El medio ambiente como una nueva dimensión del desarrollo', in René Cortázar and Joaquín Vial (eds.), Construyendo opciones: propuestas económicas y sociales para el cambio de siglo (Santiago: CIEPLAN and DOLMEN, 1998).

40 The legislative decrees overriding the Code were the Ley de Promoción de Inversiones en el Sector Minero (DL 708, Law on Promotion of Investments for Mining), passed in June I991, and the Ley Marco para el Crecimiento de la Inversión Privada (DL 757, Legal Framework for the Growth of Private Investment), passed in November I991.

${ }^{4 I}$ World Bank, Riqueza y sostenibilidad. 
policy circles. The key state actor was Jaime Solari, an engineer who returned to the country at the end of the Pinochet dictatorship after working in Britain, Brazil and Canada. Solari regretted that Chile was then 'among the few Latin American countries without environmental regulation'. ${ }^{22}$ Recruited by the Minister of Mining to deal with the smelter problem, he was closely advised by a leading expert, Gustavo Lagos. The latter was an influential adviser. In 1989 Lagos presented a rough diagnosis of smelter-caused pollution at the Third Scientific Summit on the Environment, part of a decade-long effort by scientists and engineers to alert Pinochet's officials to the absence of national environmental policy. ${ }^{43}$ With the victory of the Concertación, many of these professionals would support the new clique of technocrats. The environmental unit within the Ministry of Mining, in particular - a team of no more than four people by the mid-I990s - would consult ad-hoc studies by a pool of experts. No foreign advice was solicited, and the core of the new order for air pollution from smelters was established during the Aylwin administration $($ I $990-4) \cdot 44$

Environmental reform in Chile, however, was full of small but critical battles. That is how the agency of reform-mongers, to recall the term coined by Albert Hirshman, became fundamental for the timing, sequencing and scope of the change carried out, insightfully discussed in Paul Pierson's Politics in Time. ${ }^{45}$ It was particularly important to have the full support of the Ministry of Finance, the fundamental institution for development planning in contemporary Chile, and key members of the boards of the state-owned mining corporations, CODELCO and ENAMI. Without this, the effort would turn into a set of political good intentions and supporting scholarly studies. For the passing of cornerstone regulation, key power brokers had to be persuaded with the help of reason and charisma. Policy entrepreneurs usually operate at the limit of rules and conventions, as explained in the classic analysis of entrepreneurship by Joseph Schumpeter, in order to achieve what they consider vital change. ${ }^{46}$ Supreme Decree 185 of 1991 , which mandated the cleaning of smelters, embodied this: in the words of Jaime Solari,

CODELCO and ENAMI said, 'If we do not have the support of the Ministry of Finance it is pointless.' US\$ $\$$ roo million were needed for a sulphuric acid plant.

${ }^{42}$ Interview with Jaime Solari, 24 Aug. 2007.

43 CIPMA, Chile piensa en Chile: zer encuentro cientifico sobre el medio ambiente. Concepción, agosto 1989, vol. 5: Conclusiones (Santiago: CIPMA, 1989).

${ }^{44}$ Interviews with Jaime Solari, 24 Aug. 2007, and Gustavo Lagos, a mining engineer who advised the process closely and whose academic production benefited this research, Santiago, 23 Jul. 2007. $\quad{ }^{45}$ Hirschman, Journeys toward Progress; Pierson, Politics in Time.

${ }^{46}$ Joseph Schumpeter, The Theory of Economic Development: An Inquiry into Profits, Capital, Credit, Interest, and the Business Cycle (Cambridge, MA: Harvard University Press, 1934), p. $2 \mathrm{I}$. 
Mining is in the same building as Finance. I went to Eduardo Bitrán [a key adviser to the finance minister] ... and I said to him, 'Look, we have these polluting smelters, we have to improve this' ... a very quick chat. I gave him [Supreme Decree i 85 ] to get [Finance Minister] Foxley's signature, and he did so.

Bitrán later reproached Solari for not telling the whole truth, since the cost of the reduction effort had not been made sufficiently clear in their conversation. Solari maintained that he exaggerated the win-win solution because it was imperative to push for environmental change, even if the administration had many other priorities on which to focus its resources during the first months after the return to democracy. For Solari, cleaning the smelters was a mission Chile had to accomplish no matter what, and the sooner the better. He had passionate beliefs regarding the role of political elites in guiding the country toward environmental consciousness: 'The more a country develops, the more it is concerned with the environment; we [Chileans] could not fall behind.' Solari personified an environmentalist 'will to improve' that had developed among policy-minded mining engineers in Chile, experts who wanted to foster development while observing global environmental standards. ${ }^{47}$

The first big step had been to ensure an inflow of investments for reducing pollution; the second was to engineer an autonomous regulatory system. For reformers, the standards had to be those of the first world and the regulation had to be independent. As a result, the environmental unit of the Ministry of Mining did not ask to be in charge of environmental regulation. Such a scheme would make the regulatory system weak, in Solari's view: 'We always thought, as Michael Porter put it, that firms and countries win if they are more demanding of themselves; muscle is built if one creates the need.' 48 Hence the task of overseeing reduction plans and future environmental impact assessments was given to the new independent environmental authorities, the National Environment Commission (CONAMA) and the sub-national Comisiones Regionales del Medio Ambiente (Regional Environment Commissions, COREMAs). This contrasts with the case of Peru's Ministry of Energy and Mining, which fought to keep new environmental regulation under its jurisdiction.

In Chile, those who drafted the laws of the CONAMA (the environmental lawyers) and those who pressed for air pollution regulation in mining (the environmental engineers), supported by their respective immediate political authorities (the SEGPRES and mining ministers respectively), called for 'autonomous state institutions'.49 Bureaucratic activism at CONAMA

47 The phrase 'will to improve' comes from Tania Li, The Will to Improve: Governmentality, Development, and the Practice of Politics (Durham, NC: Duke University Press, 2007).

${ }^{48}$ Interview with Jaime Solari.

49 Interviews with Jaime Solari, 24 Aug. 2007, and Rafael Asenjo, head of CONAMA between 1990 and 1994, Santiago, I 9 July 2007. 
helped bureaucratic activism in the mining ministry, and vice versa. In particular, the piecemeal reduction of air pollution from smelters ended up working as a pilot project for the new national system of environmental regulation, not approved by Congress until 1994. Meetings of the regional authorities of the ministries of health, agriculture and mining, aimed at overseeing the smelter pollution reduction plans and discussing the need for adjustments and further regulation, became a model for the work of regional COREMAs, which would become the regulators of environmental permits and supervision of all business after the 1994 law. ${ }^{50}$

The inclination of political and professional elites to look for bureaucratic autonomy can only be understood well in the light of an in-depth reading of history. Chile illustrates how the creation of bureaucratic autonomy can essentially be a home-grown process, since it is old state capacity that eases the way for policy agents to bring in new state capacity. ${ }^{\text {I }}$ Solari and his team, and the environmental lawyers at CONAMA, were not inventing the Chilean state, but following a time-honoured tradition of ruling in the name of reason', which allows the técnicos to have relatively high-level control over the state apparatus. Historical examples of such a trend run from the Banco Estado (the state bank) and Corporación de Fomento de la Producción (CORFO, the national development corporation) to the mining companies CODELCO and ENAMI, and the industry's all-supportive agency, the Comisión Chilena del Cobre (Chilean Copper Commission, COCHILCO). All of these state organisations survived the neoliberal wave because of the institutional properties each had gained individually and collectively as part of the Chilean state. The pilot exercises in the environmental regulation of mining and the COREMAs model itself built on the endowed state capacities of the Ministry of the Interior and the other branches of the executive, and on the political legitimacy of the intendentes, the agents of the Ministry of the Interior at the regional level, who were appointed by the president, together with the centralised management of public affairs. The institutional legacy shaped entrepreneurial policy agency.

This legacy was also an opportunity. Although air pollution in mining towns did not rank high among public concerns, its spread in Santiago increasingly did. Rising political awareness of the latter helped to develop policy concern for the former. Supreme Decree i 85 regulated particulate

so Interview with Jaime Solari.

${ }^{51}$ I discuss this in greater depth in Orihuela, 'How Do "Mineral-States" Learn?'; and in 'Building and Re-engineering "Good Governance" in Chile', in Rosemary Thorp et al., The Developmental Challenges of Mining and Oil: Lessons from Africa and Latin America (London: Palgrave Macmillan, 2012), pp. 19-43. On Chile's state capacity and the elite networks in which it is embedded, see Patricio Silva, In The Name of Reason: Technocrats and Politics in Chile (University Park, PA: Penn State University Press, 2008). 
material, sulphur dioxide and arsenic emissions throughout the national territory, north and south of Santiago, on the basis of the constitutional right to live in a pollution-free environment. With the help of their supportive network of experts, green reformers at the Ministry of Mining systematised evidence showing that 90 per cent of national sulphur emissions were produced by the mining industry. ${ }^{52}$ In other words, the political message of the network of engineers concerned with the environment was that pollution in Santiago may have been the most visible problem, but it was not necessarily the worst one. The regulation established different air quality standards for the north and south of the country. The less stringent standard was for the north, where the Potrerillos and Chuquicamata smelters are located. A higher standard was set for the south, because emissions from the Caletones smelter (located in the El Teniente division of CODELCO) had a higher direct human impact. The fumes from Caletones reached the city of Rancagua and contributed to Santiago's air pollution.

To an extent, there had been some piecemeal policy change before Supreme Decree i 85 , but effective efforts were neither swift nor substantial. A strategic assessment contracted during the tenure of the executive president of CODELCO, Gastón Frez (1978-82) (a central figure behind the nonprivatisation of the copper giant, which led to a type of neoliberalism that retained economically and politically strategic state-owned enterprises), concluded that the first priority for the corporation was environmental rather than productive: tailings dumps were about to collapse, and the situation at the El Teniente mine - which, unlike Chuquicamata, has agriculture and population centres nearby - was critical.53 Decisions were taken at CODELCO to address a number of emergencies at smelters and with tailings systems. In the early 1980 os a corporate committee for environmental control was set up to monitor air and water quality at critical points and the corporation assessed measures to reduce gas emissions in Chuquicamata, including the construction of a sulphuric acid plant. ${ }^{54}$ Corporate social responsibility was a term not yet coined. The debt crisis and the fact that CODELCO's revenue went to fiscal coffers, with the result that Ministry of Finance authorities made decisions about it, meant that investment in more environmentally friendly technologies was considered to be out of the question.

With the arrival of the Concertación, the initiatives of environmentally minded technocrats at the Ministry of Mining received a positive response

52 See, for instance, Lagos, 'Un análisis de la situación del medio ambiente'.

53 Interview with Gastón Frez (member of the junta's Advisory Committee, marketing vice-president of CODELCO in 1976-7 and executive president in 1978-82), Aug. 2007.

${ }^{54}$ See the CODELCO yearbooks for 1979 and 198 I respectively: CODELCO, Memoria Anual (Santiago: CODELCO, 1979, 1981). 
from the new management of the state-owned corporation. In 1990, the first environmental unit was created within CODELCO's communications department; it was later moved to the development department. In 1994 the environmental division was established, reporting to the vice-presidency for development. 55 A more proactive CODELCO, in the environment as well as on all other fronts, developed during the second Concertación administration (1994-2000). The year I 993 had been particularly difficult. The davilazo, a corruption scandal involving financial trading, had left the corporation at the mercy of those critical of its state-owned status. ${ }^{56}$ Calls for privatisation came from economists, the right-wing political spectrum and local interests in the Sociedad Nacional de Mineria (National Society of Mining, SONAMI). ${ }^{57}$ The new CODELCO administration (this changes with each new government) came on the scene full of vigour and aiming to prove that the state was capable of managing the state enterprise in a 'private-efficient' fashion. CODELCO began to play sensible politics, associating with foreign businesses to create the Consejo Minero (Mining Council) in I998, a move that left the political opposition of SONAMI and the right-wingers stranded. The Concertación and CODELCO were good business for foreign investors; CODELCO was to be a partner of private firms not only for joint ventures, but as a strategic ally for a broader industrial agenda. Improving the environmental reputation of the industry was part of the deal, since the multinationals followed their own higher standards. ${ }^{58}$

The two key state actors in these manoeuvres and during a decade of empowered CODELCO management were Marcos Lima, an engineer, and Juan Villarzú, an economist. Lima and Villarzú had strong political support which they transformed into greater bureaucratic autonomy, financial in particular, for CODELCO, organising a first-class team of executives. Lima was CODELCO deputy president in $1994-5$ and executive president in I 996-2000. Villarzú was CODELCO executive president in 1994-6 and 2000-5, and minister of SEGPRES in 1996-8. No significant cases of corruption or waste emerged after the davilazo. At present the model of stateowned mining is still criticised in a number of quarters, but not with allegations of incompetence or rent-seeking bureaucratic behaviour. On purely pragmatic grounds the new management of CODELCO understood that the future of the corporation had to be greener: maintaining access to international markets demanded it.59 From 1999 onwards, transparency

"S CODELCO, Memoria Anual (Santiago: CODELCO, 1994).

${ }^{56}$ The scandal was named the 'davilazo' after Juan Pablo Dávila, chief of the Department of Futures Markets at CODELCO. Dávila re-entered jail in 2007 for an eight-year sentence. For accounts of the scandal, see El Mercurio, 17 Oct. 2006 and I 8 March 201 I.

57 See SONAMI's Boletin Minero.

${ }^{58}$ Interviews with Marcos Lima, 24 July 2007, and Juan Villarzú, 17 Aug. 2007. 
became regular practice with the publication of annual sustainability reports, which currently include data on emissions of pollutants and consumption of energy and water, as well as generation of solid and liquid waste. ${ }^{60}$

The regulatory process was not free from controversy or failure. In particular, the environmental standards defined in the first reduction plan in 1993, which Ministry of Mining officials had agreed with CODELCO executives, ended up being too onerous for the state-owned company. ${ }^{61}$ In 1998 the copper giant requested a reformulation of the abatement timetable to enable it to meet regulatory standards, which the government would approve in 2000. By the late 1990 S Chuquicamata had done its homework and was fulfilling government emissions norms. Until then, however, CODELCO's efforts to achieve air quality standards had proved to be insufficient. The Antofagasta Regional Health Service fined the firm for failing to meet air quality standards in 1999. Empowered by the national legislation of 1994, regional state institutions went to work. CONAMA declared Chuquicamata to be a 'saturated zone' of sulphur anhydride and particulate material in I99 I, and only changed its status to that of a 'latent zone' i 4 years later. However, the relocation of workers from the mining town to the city of Calama reduced the impacts of pollution on the population. ${ }^{62}$

To summarise, the cleaning up of Chuquicamata and the other state-owned smelters was not the result of an automatic, radical shift at a critical juncture, as some analytical frameworks of institutional change might lead analysts to expect. Instead, it was the result of the progressive crafting of political will and policy muscle across the state apparatus, within a process shaped by contingencies. Although one would not want to disregard the central significance of cornerstone regulation, in the shape of Supreme Decree i 85 of I991 or the National Environmental Law of 1994, policy change was primarily the outcome of a decade-long battle resolved within the political system, in the first place by technocrats and politicians from one coalition but different government branches: CODELCO, CONAMA, the Ministry of Mining and the Ministry of Finance. It was not a simple task to reconcile health, environmental and economic perspectives among members of the same political platform; a coalition of will had to be built. Reformers successfully presented the cleaning of the smelters as both a problem of the past and a possibility for the future: paying for old sins would bring greater compensations, environmental as much as economic, down the road. Given the contingency of regime change and favoured by a state institutional

59 Ibid.

${ }^{60}$ See www.codelco.com/reportes/prontus_codelco/20 I I-07-08/I 54944.html.

${ }^{61}$ Interview with Jaime Solari.

${ }^{62}$ CONAMA, 'Informe de seguimiento: plan de descontaminación de Chuquicamata, año 2005 ', Santiago, 2006. 


\section{José Carlos Oribuela}

tradition embedded in a robust political party system, a network of 'experts turned statesmen' established a regulatory system with a significant degree of autonomy which meant that achieving progress was the responsibility of public servants independent of the Ministry of Mining. Between 1989 and 2002, state-owned smelters invested some US\$ I.5 billion in order to adjust their operations to meet new air quality standards; half of the expenditure was concentrated in Chuquicamata. ${ }^{63}$ The outcome was a sharp reduction in emitted pollutants, as Figure I shows.

\section{Constrained Reformers in Peru}

Environmental policy entrepreneurs were not a development exclusive to the Chilean state. In Peru, however, such leadership was not only scarcer but took place within a political economy system that was less favourable. There were fewer positive contextual factors, whether institutional or contingent. As a result, even though mining was, as in Chile, the primary emphasis for formal environmental policy change, sectoral reform was weak and inconsistent with other government actions. The beginning of environmental reform in Peru was not, for the most part, an autonomous process but, fundamentally, the outcome of globalisation forces: the World Bank conditioned its support for the privatisation of mining and oil on the creation and strengthening of 'environmental institutions' in the Ministry of Energy and Mining.

Government officials in Peru in the I 990 s were highly distrustful of the role of the state in the functioning of the economy. The first Fujimori cabinet included a mix of laissez-faire and interventionist ministers - with the top authorities of the Ministry of Energy and Mining, for instance, opposed to privatisation across the board - but the former group soon took control of economic and mining policy. ${ }^{64}$ The future of the Empresa Minera del Centro del Perú (Central Peru Mining Company, CENTROMIN), the state-owned mining company in central Peru which owned the smelting and refinery facilities at La Oroya, had been the subject of struggle between the factions. Nevertheless, leading CENTROMIN engineers and economists ended up supporting privatisation on pragmatic grounds: in the words of one key figure, 'The big idea was to promote private investment because the state had failed.' ${ }^{5}$

${ }^{63}$ COCHILCO, 'Análisis de inversiones ambientales en las fundiciones estatales de cobre', Santiago, 2003.

${ }^{64}$ Interviews with María Chappuis, Is Feb. 2008, and César Polo, 3 Apr. 2008. Both were central colleagues of Fujimori's first mining and energy minister, Fernando Sánchez Albavera.

${ }^{65}$ Interview with César Polo. Polo had been finance manager of the state-owned mining firm CENTROMIN between 1980 and 1989 , deputy mining minister in $1990-1$, general manager of COPRI, the privatisation agency, between I99I and 200I, and deputy mining minister again between 2002 and 2006. On the case for mining and energy policy in Peru, see Fernando Saánchez Albavera, Las cartas sobre la mesa (Lima: DESCO, 1992). 
Figure I. Air Pollution in Chuquicamata
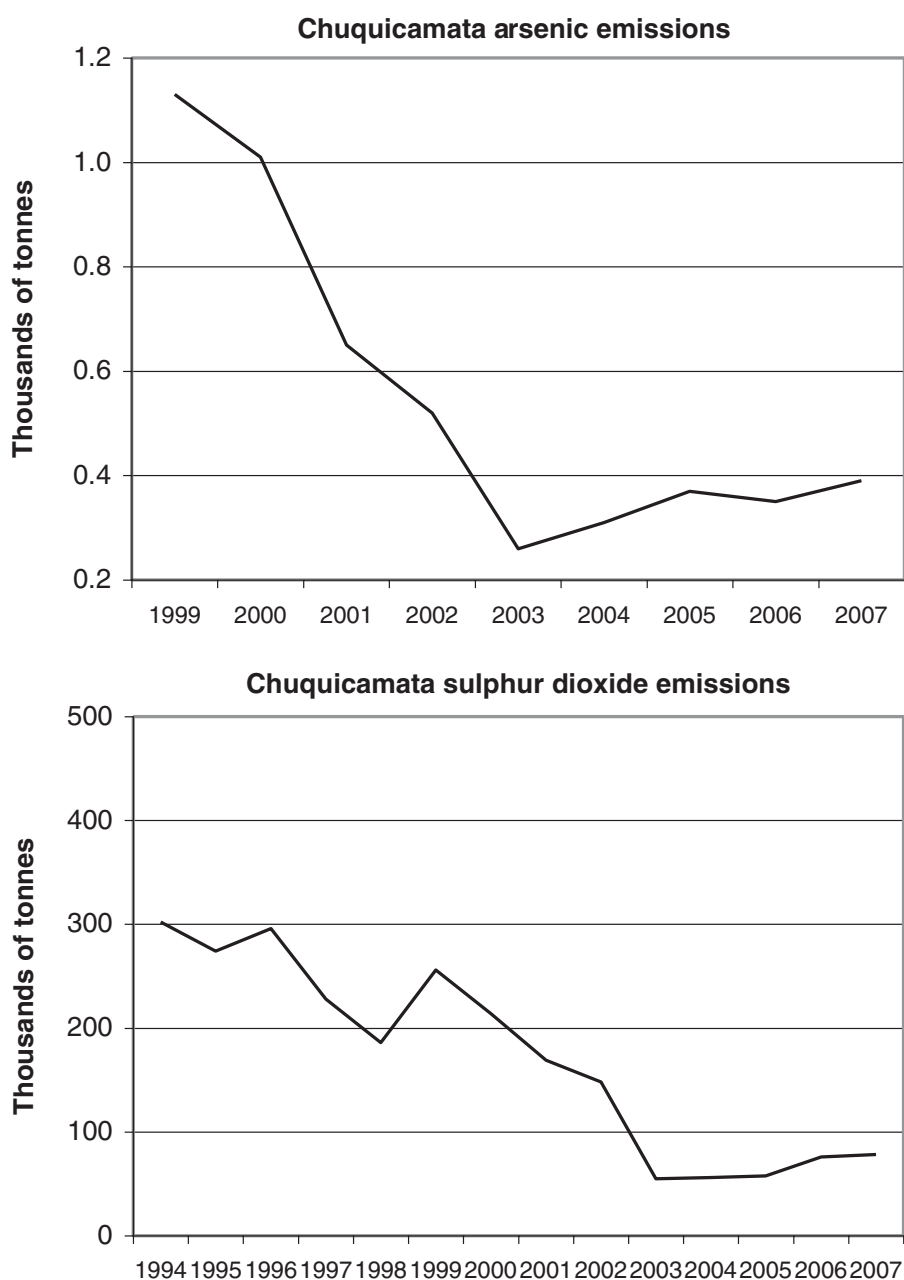

Source: author's elaboration from CONAMA monitoring reports and CODELCO yearbooks.

Unlike Chile, the triumphant neoliberal project did not want or have to make an accommodation with strategic state-owned enterprises. While the big idea was to bring in fresh capital to save mining and the economy in general, and La Oroya in particular, environmental well-being did not rank high in the belief systems of former CENTROMIN officials who had been transformed into privatisation and regulation bureaucrats; it was World Bank officials who pushed for the new doctrine. Nor was it important for top policy-makers in the economy and finance field: environmental policy is not mentioned in La reforma incompleta, a two-volume assessment of the accomplishments and 


\section{José Carlos Oribuela}

failures of a decade of structural reform, edited by leading figures of Fujimori's economic team. ${ }^{66}$

The depth of distrust that political and policy elites in the Fujimori administrations showed in the state needs to be read once again in light of history. The strong belief that 'the state' was inherently incapable of taking over new assignments is largely a consequence of the high volatility of the Peruvian political system, which led to a 'democracy without parties' and a poor democratic tradition over the long term. As a consequence of two centuries full of new political beginnings and high-profile corruption, the Peruvian state has less of a 'national project' quality than that of Chile. ${ }^{67}$ Old and new political leaders feel largely alienated from this, and relatively few among the wealthy and the educated are willing to become its agents. The reservoir of Weberian bureaucrats is small, and that of potential 'technopols' even slighter; the public-minded network that embeds it, thin. ${ }^{68}$ In a highly endogenous process, old state failure brings in new state failure, of which CENTROMIN was just one of many examples that did not survive the I 990 os. There was no bureaucracy in the Ministry of the Interior or at the regional level that one could trust on the delegation of environmental regulation equivalent to the COREMAs. In short, it is no surprise that, despite its inbuilt distrust of state action, neoliberalism finally followed two contrasting regulatory paths in Chile and Peru. State capacity and legitimacy at the onset gave birth to neoliberalisms with a strong and a weak state respectively.

It is because the bureaucrats do virtually nothing that the lawmakers, as well as grassroots leaders, appear so active. The lack of ownership of 'green reforms' by Peru's authorities means that, rather than being indicators of effective state action, the number of new acronyms in the state apparatus or an index of new 'green' legislation and regulations expresses precisely the opposite: state inaction. ${ }^{69}$ So even though a 'new deal' for the environmental regulation of mining was formally established in $1992-3$, air quality standards were not set until 1996, the first remediation plan for La Oroya was put on hold until the plant's privatisation in 1997 , and the enforcement of standards and

${ }^{66}$ Roberto Abusada, Fritz Du Bois, Eduardo Morón and José Valderrama, La reforma incompleta: rescatando los noventa (Lima: Universidad del Pacífico and Instituto Peruano de Economía, 2000).

${ }^{67}$ Key readings influencing this view are Jorge Basadre, Perú: problema y posibilidad (Lima: Banco Internacional del Perú, 1978 [193 I]); Julio Cotler, Clases, estado y nación en el Perú (Lima: IEP, 1978); and Alfonso Quiroz, Corrupt Circles: A History of Unbound Graft in Peru (Washington, DC: Johns Hopkins University Press, 2008).

${ }^{68}$ On 'technopols', see Alfredo Joignant, 'The Politics of Technopols: Resources, Political Competence and Collective Leadership in Chile, 1990-2010', Journal of Latin American Studies, 43: 3 (201 I), pp. 517-46.

69 For a legal history of new environmental regulation, see Pulgar-Vidal and Calle, Para hacer tortillas hay que romper huevos. 
plans never actually happened.70 The new deal started in 1992, when the government created the Dirección General de Asuntos Ambientales (General Directorate of Environmental Affairs, DGAA), the first department of its kind in the history of the Ministry of Energy and Mining, to work as the environmental authority. Then, in 1993, the government signed up for an Energy and Mine Technical Assistance Loan (EMTAL) Project with the World Bank, which is 'credited with catalysing many key regulatory and institutional changes that promoted sustainable practices in the mining sector'. $7^{1}$

Looking at the record of regulatory capacity-building, the gap between law and discourse, on the one hand, and bureaucratic capacity and effective reach, on the other, becomes more tangible. A decade after environmental reform started, the DGAA had only six technical staff members approving environmental impact assessments and overseeing compliance with national regulations from Lima. ${ }^{2}$ By 2008 , the number had increased to 'close to Io professionals for mining and 10 for energy'. ${ }^{73}$ As part of the World Bank's suggested institutional reforms, the DGAA had been created within the Ministry of Energy and Mining. Unlike Chile's CONAMA, Peru's new national environmental authority, CONAM, which was created in I994, was given merely a coordinating role, while ministries remained the environmental authorities for their economic sectors. However, the energy and mining authorities did not construct the necessary supervisory capacities to make formal regulation by the DGAA a reality. ${ }^{74}$

The scant existing regulation for La Oroya emerged only a decade after formal regulation was established, pushed by the metastasis of socioenvironmental conflict across the national territory. ${ }^{75}$ Contentious activism against big mining, however, occurred virtually everywhere but in La Oroya, where civil society activism took a subtler form, that of the Movimiento por la Salud de La Oroya (La Oroya Health Movement, MOSAO). ${ }^{6}$

70 See Ministerio de Energía y Minas, Resolución Ministerial 31 5-96-EM/VMM, i 9 July I 996; and ESAN, 'Evaluación de la solicitud de prórroga excepcional de plazos para el cumplimiento de proyectos medioambientales específicos presentados por la empresa Doe Run Perú SRL', Lima, 2006.

${ }^{71}$ World Bank, Riqueza y sostenibilidad, p. 65.

${ }^{72}$ Ibid., p. 75 .

${ }^{73}$ El Comercio, 30 Nov. 2008. Visiting the DGAA in 2007 and 2008, I saw a handful of young engineers facing the impossible task of assessing a room full of voluminous environmental reports.

74 Although the country had regional-level regulation in the form of the COREMAs, the criticism in Chile was that in practice environmental impact assessments were carried out and supervised by industry-funded experts.

75 See Defensoría del Pueblo, 'Informe extraordinario'.

${ }^{76}$ MOSAO was established in 2002 by La Oroya activists. On MOSAO and civil society activism in La Oroya, see Martin Scurrah, Jeannet Lingán and Rosa Pizarro, 'El caso de La Oroya', in Scurrah (ed.), Defendiendo derechos y promoviendo cambios, pp. 69-136; and 


\section{I74 José Carlos Oribuela}

Eventually, in 2006 , the duty of overseeing the remediation plans of privatised mining units was passed to the regulator of energy prices and market competition, the Organismo Supervisor de la Inversión en Energía y Minería (Supervisory Body for Investments in Energy and Mining, OSINERGMIN, originally created in 1996 as OSINERG after the privatisation of energy), while the Ministry of Energy and Mining's DGAA kept all other regulatory functions (ex-ante impact evaluation assessments and the regulation of all new mining). In the interim, an internal proposal to establish an ad-hoc regulator had been rejected. ${ }^{77}$ OSINERGMIN bureaucrats had to learn their new duties fast, illustrating how state institutions often end up working towards purposes other than those for which they were created. In 2007 OSINERGMIN gave Doe Run its first environmental fine (approximately US\$250,000) after ten years of regulatory leniency. The violations were serious: the company had exceeded mandated air quality standards and dumped effluent into the Mantaro River in three places without treatment or permits, it lacked a comprehensive environmental management system for its sulphur dioxide emissions, and it practised careless truck transportation of hazardous material. Nevertheless, demonstrating the constraints on its executive scope, OSINERGMIN only 'recommended' that Doe Run should resume the functioning of mandated monitoring points and publish air monitoring results on the company website. ${ }^{78}$

From the sale of La Oroya to Doe Run in 1997 to the first fine imposed by OSINERGMIN in 2007, bureaucrats in the Ministry of Energy and Mining granted four extensions to the company's environmental management plan. The first remediation plan was estimated to cost US\$ i०8 million for I 998-2006 (less than ro per cent of CODELCO's investments and less than half of ENAMI's), and its central US\$ 90 million expenditure on a sulphuric acid plant was not to start before 2003. As a clear signal of how low a policy priority air pollution was, mandated upgrades in air quality standards ignored the critical problem of lead pollution. In 2006 the company claimed once more that financial constraints made new investments in green technology unfeasible. The Ministry of Energy and Mining commissioned a local

Cederstav and Barandarian, La Oroya Cannot Wait. After finishing this article, I learned of two recently completed unpublished manuscripts: Areli Valencia, 'Human Rights TradeOffs in a Context of Systemic Unfreedom: Work vs. Health in the Case of the Smelter Town of La Oroya, Peru', unpubl. PhD diss., University of Victoria, Canada, 20 I2; and Fernando Bravo Alarcón, 'El problema ambiental de La Oroya y su construcción social y política a través del análisis de las propuestas institucionales, legales y participativas de remediación', unpubl. MA diss., Pontificia Universidad Católica del Perú, 20 I 2.

77 Interview with César Polo.

${ }^{78}$ OSINERGMIN, 'Informe: examen especial sobre normas de protección y conservación del ambiente realizado en el complejo metalúrgico La Oroya', Lima, 2007. 
university to evaluate the new 'exceptional request' for an extension (its fourth!). The reduction plan was by then estimated to cost US\$ 196 million. Days before the government responded to the request, journalists from El Comercio reported that the financial difficulties were the result of Doe Run Perú having remitted more than US\$ roo million in profits to its US head office, the US-based Renco Group (see payments to associated branches in Table 2).79 Afraid of losing their jobs, the workers' unions demonstrated in favour of Doe Run, not only in La Oroya but also in Lima, including at the headquarters of El Comercio, turning the most clear-cut case of mining pollution into a source of pro-mining mobilisation. The Ministry of Energy and Mining granted the extension. In 2009, a new appeal reached the ministry and Congress. The new government's authorities approved a fifth extension.

OSINERGMIN fined Doe Run after a second and more autonomous environmental policy reform process, if still a weak one, had started. The end of Fujimori's government in 2000 signalled a shift in the opportunity structure. The largest state-owned mining enterprises, CENTROMIN and Minero Perú, had been privatised, so that there was more political space to press policy-makers to clean up the industry. Moreover, the most radical freemarket economists had already lost power with the 1997-8 financial crisis, and the return to full democracy in $200 \mathrm{I}$ opened the door to economic authorities with a less limited repertoire of public policy. Above all, the return to democracy meant that the discontent could be expressed more freely and civil society could advocate more effectively, and so 'socio-environmental conflict' associated with mining could no longer be ignored by the establishment, composed of big business, the national press and the central government. $^{8 \circ}$

Driven by new environmental awareness or plain political pragmatism and a sense of public duty, technocrats slightly more inclined to market regulation gained power during the first term of Jaime Quijandría as minister of energy and mining $(200 \mathrm{I}-3)$. The call was rather minimal, simply to enforce the formal rules put in place since $1992-3 .{ }^{81}$ As a way to back enforcers of environmental norms and to build in legitimacy, since neither top government authorities nor the business community sympathised with greater environmental regulation, the minister requested the World Bank office in Lima to assess state organisational developments and government measures to address socio-environmental problems. ${ }^{82}$ However, the reformist camp lost even this limited political backing once Quijandría switched posts to become minister

79 El Comercio, 2 June 2006. That the economic pages of the mainstream press criticised the environmental record and business practice of mining was then a novelty. ESAN's report (see note 70 ) confirmed the allegation.

${ }^{81}$ Interview with Jaime Quijandría, 20 Dec. 2008.

${ }^{8 \circ}$ See note 3 .

${ }^{82}$ Ibid. 
Table 2. Doe Run Abatement Plan and Cash Flow (US\$ Million, Current Values)

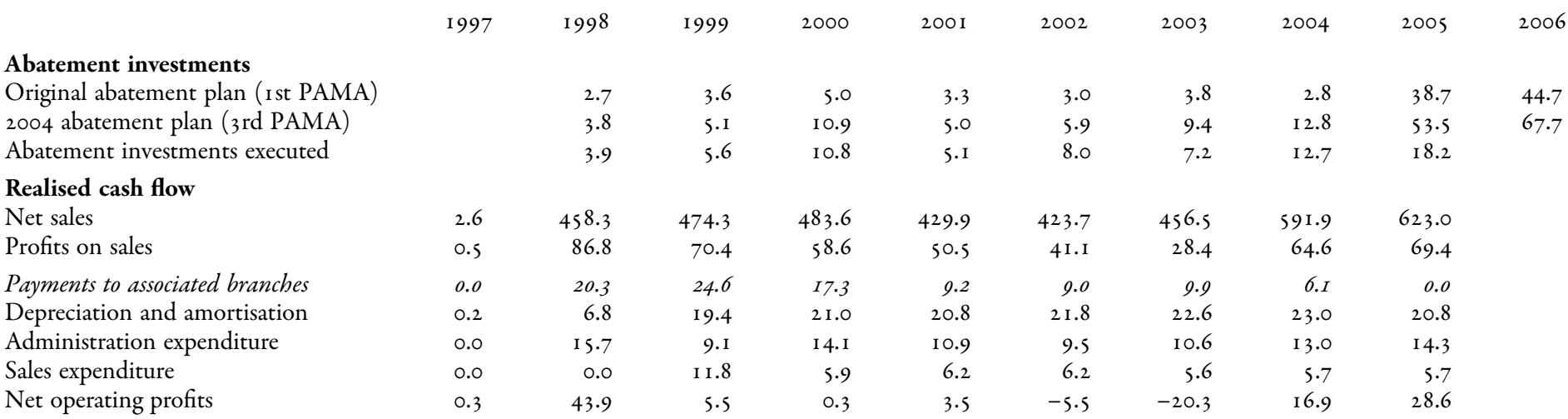

Source: ESAN, 'Evaluación de la solicitud de prorroga excepcional de plazos para el cumplimiento de proyectos medioambientales específicos presentados por la empresa Doe Run Perú SRL', Lima, 2006, pp. 16, 76. 
of finance and an even more business-friendly administration took over the Ministry of Energy and Mining. By the time Quijandría had returned in late 2004, a key government official, María Chappuis, had resigned and the ministerial agenda was basically limited to finalising the highly controversial Camisea gas project (in the southern Amazon region), which was opposed by a transnational coalition of environmental activists. ${ }^{83}$ Critical to the development of regulations for La Oroya was the approval in March 2004 of a ministerial decree easing constraints on the rescheduling of pollution remediation plans. The decree was apparently drafted to favour the company that owned La Oroya. ${ }^{84}$ In the words of María Chappuis:

The position of the Directorate of Mining [of the Ministry of Energy and Mining] was that we should not grant more time to Doe Run, since it had fulfilled only 25 per cent of its remediation plan ... I resigned because Decree [DS 046-2004-EM] had a name: Doe Run was the only company that used it ... Each time Doe Run was in trouble, [the company] went to the Ministry's Secretary of Environmental Affairs and obtained extensions, which were irregular. That is how they avoided fines and left remediation investments to the end. ${ }^{85}$

With a government incapable or unwilling to take action against Doe Run, by the time profits had been remitted to headquarters, in the nominal form of repayment of debts that Doe Run Perú had with the Renco Group, the problem was presented by the company as a policy dilemma: jobs versus public health. Doe Run argued that it would have to close its operations if environmental engineering investments were enforced. With no counterbalancing leadership from the government and since the environmentally minded elements of civil society had little influence among the upper echelons of policy power, government decisions were taken by the circles of power and framed as the company wanted. Not only were the trade unions afraid of job losses, but high-ranking technocrats also stated that it was counter-productive to increase the costs of an economic activity that generated economic progress. The precedence given to jobs and growth over the local population's health was so eloquent that those within the government who favoured granting Doe Run Perú a fourth extension, including the deputy mining minister himself, suggested a local referendum to decide the issue. ${ }^{86}$ The extensions had supposedly been granted as a result of an objective cost-benefit analysis of the greater public good. There were environmental costs, but also economic

${ }^{83}$ On Camisea, see Defensoría del Pueblo, 'El proyecto Camisea y sus efectos en los derechos de las personas', Informe defensorial no. I03, Feb. 2006; Carlos Soria, 'Camisea: ¿por qué cuesta tanto el gas barato?', Iconos, 2 I (2005), pp. 47-55; and Catherine Ross, 'El caso del proyecto Camisea: logros y limitaciones de una coalición ciudadana floreciente', in Scurrah (ed.), Defendiendo derechos y promoviendo cambios, pp. 199-268.

${ }^{84}$ Ministerio de Energía y Minas, Decreto Supremo 046-2004-EM.

${ }^{85}$ El Comercio, 4 Mar. $2006 . \quad{ }^{86}$ Ibid. 


\section{José Carlos Oribuela}

benefits to consider. On balance, the status quo was positive for the country and there was no need to risk moving to a different policy equilibrium. That is the argument the Peruvian government used to respond to the World Bank's critical report on the country's extractive industries: a utilitarian rather than a social justice-based paradigm had to be observed in the evaluation of mining activities. As the official statement on the report argued:

Within the premise of sustainable development that all countries want to achieve, there are three aspects to take into account, all of them indispensable: the social, the environmental and the economic. The Extractive Industries Report discusses and highlights the social and environmental dimensions, but disregards the economic one. An objective analysis of mining cannot be made without a comprehensive assessment. ${ }^{87}$

Peruvian government officials in three successive administrations (Fujimori, Toledo and García) supported the economic interests of Doe Run in La Oroya in the name of the greater public good. Air quality standards when La Oroya was privatised were set low; comprehensive studies of the quality of air, water and soil were not conducted; extensions to environmental requirements were granted regularly; and even the prime minister lobbied the US embassy in Lima against a class action suit against the company lodged in the United States, as described below. All of these actions and omissions were carried out under the declared belief that they were best for the Peruvian people. While it is difficult to ascribe motives to observed behaviour, it is a fact that there was a revolving door between the regulator and the regulated: two heads of the environmental section of the Ministry of Energy and Mining, both of whom were former CENTROMIN employees, later became employees of Doe Run. ${ }^{88}$

For the company, responsibility for the public good seemed to end where the economic benefits that its activities generated began. A new company, Doe Run Perú, was created in 2007, formally independent of the Doe Run Resources Corporation in St Louis, Missouri, and wholly owned by Doe Run Cayman Islands as a means to protect the Missouri-based company from environmental lawsuits associated with its former subsidiary in Peru. This happened when the government office, OSINERGMIN, was assigned the duty of overseeing Doe Run and imposed a fine and recommendations while a group of nuns in the United States who had joined the MOSAO cause took the case of the health impacts of the La Oroya plant to the St Louis courts. The evolution of the latter case illustrates the idiosyncrasies of the political economy of development in Peru. Prime Minister Jorge del Castillo was persuaded by

\footnotetext{
${ }^{87}$ Ministerio de Energía y Minas, 'Opinión del Perú sobre el informe final de la revisión de las industrias extractivas al Banco Mundial', p. i 4.

${ }^{88}$ El Comercio, 4 Mar. 2006.
} 
Doe Run to write a letter to the US ambassador asking for intervention to prevent the court in St Louis from admitting jurisdiction in the case, which would go 'against the principle of national sovereignty'. Del Castillo stated that the letter was written on behalf of the 'national interest', arguing that the lawsuit could threaten foreign investments and the ratification of a free trade agreement with the United States. ${ }^{89}$ While international trade had been used as a rationale for strengthening environmental regulation in Chile, the opposite happened in Peru.

Not only was support from the Ministry of Energy and Mining and other government authorities weak, but reformers also found little help in La Oroya's owner and the domestic mining industry as a whole. It was not early elite responsiveness, as with Chuquicamata in Chile, but the emergence of protest against mining that grew after the fall of Fujimori in 2000, which finally placed the environmental issue on the agenda of public debate. Escalating political protest was not matched by government leadership. The dominant discourse of authorities and leaders of opinion held modern mining to be incapable of polluting and demonised environmentalism. Government officials and business leaders expressed their fears about the 'hidden intentions' of NGOs, Church activists and grassroots opposition. Neither the government nor the industry was interested in a high-profile crusade for a more environmentally responsible mining sector, believing as they apparently did that it would have empowered social movements threatening economic progress and political stability. In contrast with the CODELCO-Mining Council dynamic observed in Chile, which generated a public-private partnership for a greener industry, the Peruvian state had in the Sociedad Nacional de Minería, Petroleo y Energía (National Society of Mining, Petroleum and Energy, SNMPE) an interest group that was far more reactionary in the face of any regulation that could 'threaten competitiveness'. For instance, the SNMPE was one of the most active business associations opposing the General Environment Law, passed in 2006 after five years of bitter debate. The SNMPE pulled foreign companies into a highly conservative political game, which could be partly explained by the fact that most Peruvian mining companies operating in the central Andes were medium-sized firms with poor environmental records and thus presumably not particularly keen on raising environmental standards. Later on, the rise of environmental opposition to proposed oil and gas exports in the Amazon basin, associated with the second phase of the Camisea project, became a cause for transnational activism and favoured the 'business as usual' forces within the industry. ${ }^{\circ}$ It was not until Doe Run Perú stopped honouring

${ }^{89}$ La República, I I and I 6 Jan. 2008.

90 The representative of Hunt Oil in Peru became the president of the SNMPE. The company leads the consortium organising the Camisea export business. 
its debts to the domestic medium-sized industry that the SNMPE first suspended and then disaffiliated it, in January 20 10.

More significantly, there was no positive synergy with the industry because the Peruvian state had sold the La Oroya complex to a company with questionable social responsibility practices. In 1994, three years before buying La Oroya, Doe Run had acquired a smelter built in 1892 in the town of Herculaneum, Missouri. Over two decades the US Environmental Protection Agency (EPA) and the Missouri Department of Natural Resources struggled to make the smelter comply with air quality standards. In $200 \mathrm{I}$ an abatement order was issued to Doe Run to cease all activities that caused fugitive dust and to upgrade its facilities, among other measures. ${ }^{91}$ In 2005 the Missouri Coalition for the Environment took the case of lead air quality standards to the St Louis District Court, which ruled that the EPA had to complete a review of scientific evidence and determine whether a new air quality standard was needed. In October 2008 the EPA reduced the airborne lead standard from I.5 to 0.15 micrograms per cubic metre. Another controversy involving the Renco Group, which was decided in its favour, dealt with air pollution and toxic waste dumped in the Great Salt Lake, Utah, in a case filed by the Justice Department and EPA.92 Doe Run was not among the 37 oil and mining companies supporting the UK-sponsored global Extractive Industries Transparency Initiative (EITI) launched in 2002, or any other similar initiative. ${ }^{33}$ As a result, corporate information in general and environmental performance indicators in La Oroya in particular were only available from reactive media announcements by the company. In 2009 Doe Run Perú announced the suspension of operations because of liquidity problems. In 2012 the company was declared bankrupt. ${ }^{94}$

\section{Conclusion}

Can the environmental regulation of smelters become a policy priority when it does not affect the elites and does not rank high in the grassroots? The Chuquicamata case says yes. The success story needs to be qualified, since it

91 State of Missouri, 'Order to Abate and Cease and Desist Violations, Department of Natural Resources, 25 September 200I'. All relevant information is available at www.dnr.mo.gov/ env/herc/herc_abate.htm.

${ }_{92}^{2}$ In a more recent controversy, Renco bought Sparrows Point steel mill, once a driving force of the Baltimore economy, in $20 \mathrm{I}$, only to file a controversial Chapter i I bankruptcy a year later: see www.reuters.com/article/2012/05/3 I/rgsteel-bankruptcy-idUSL IE8GV 36 W20I2053I.

${ }^{3}$ CODELCO does not participate in the EITI either, but belongs to the Global Reporting Initiative: see COCHILCO, 'Defensa regulatoria del cobre en el ámbito internacional 2000-2005', Santiago, 2006.

${ }^{94}$ La República, I 4 April 2012. 
Figure 2. Air Pollution in La Oroya
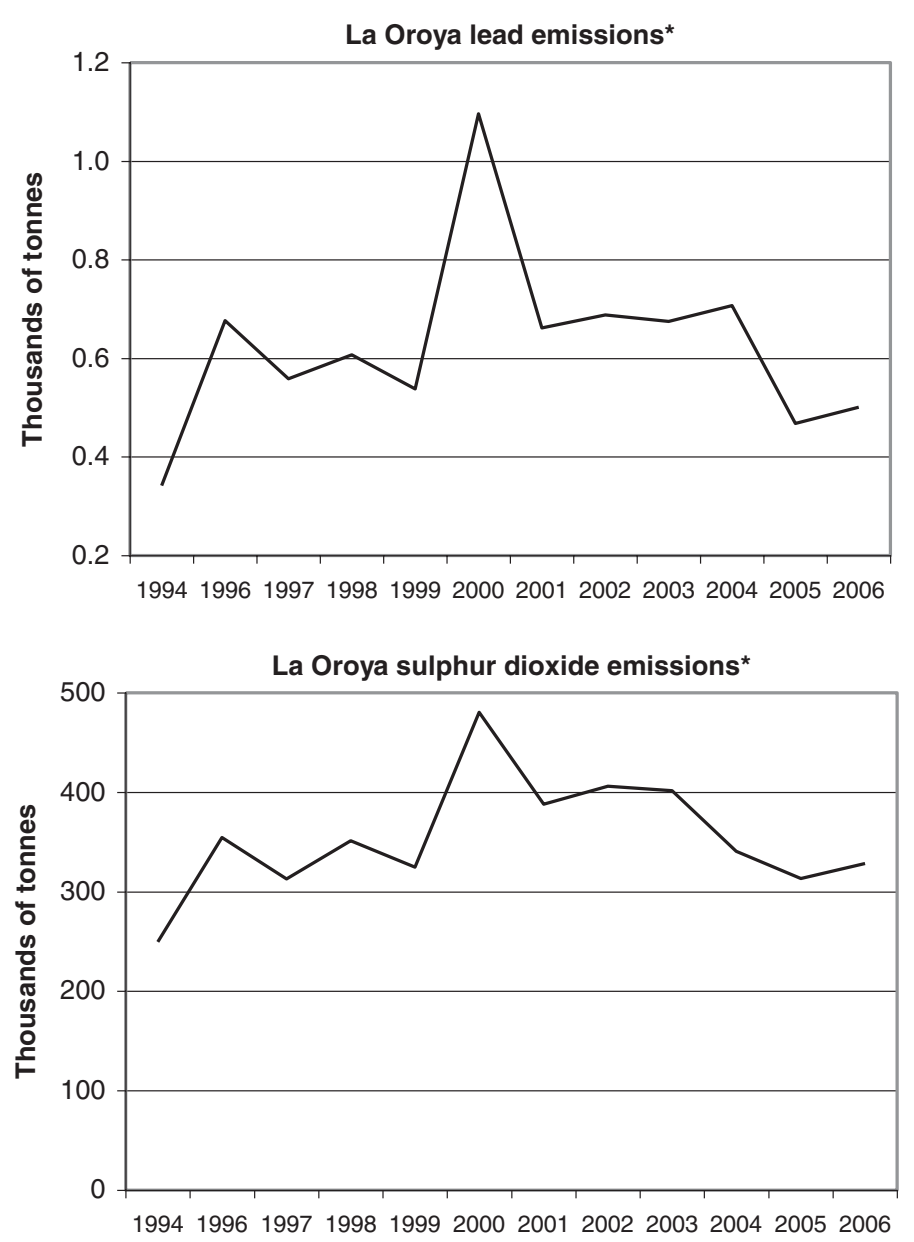

* La Oroya's graphs are based on average sampled monthly data from the smelter's main chimney only. In press notes, Doe Run maintained that lead emissions had decreased sharply since 1997, but supporting information was not made public.

Source: author's elaboration using monitoring data from the Ministry of Energy and Mining of Peru.

may not look as 'green' when compared with other cases or viewed through more comprehensive lenses, but substantial progress has been achieved. In 1990 , with the first of the chain of events that led to the emergence of environmental reform, Chile had old institutional structures and new environmentally conscious technocrats in office with relevant know-how and good relationships with experts and politicians. The policy culture was moving away from extreme market fundamentalism, although it stressed 


\section{82 José Carlos Oribuela}

macro-economic conservatism and the need for international trade integration, the latter useful to the environmentalist crusade that brought in CONAMA and the National Environmental Law. These important contextual characteristics are not sufficient on their own to explain the timing and reach of policy change that occurred. Political willingness and policy entrepreneurship within state institutions also had to be present at the time when they were needed.

In Peru, the rules of the game changed little. There was certainly more environmentalist activism at the grassroots level than in Chile, but elites were conversely less interested in the matter. The national experience shows how collective action can be more vigorous and more prone to engaging in contentious forms precisely because of the failure of the elites and the formal political system to recognise and address failure and grievance. When environmental reform of the mining industry was attempted in Peru, there were fewer of the favourable institutional and contingent characteristics listed for Chile. Moreover, and largely as a consequence, policy leadership was scarcer. Environmentalist interests in civil society found weak structures to build on and feeble partners with which to associate in the state and the formal political system. What is more, not only was the institutional environment less positive in Peru, but ecological and socio-economic conditions had historically presented broader challenges to mineral-based development: the first mineral deposits exploited were less profitable, so old industrial-scale mining was not in good shape; the hosting ecosystems were more fragile, so environmental liabilities were larger; the economy was less developed and less integrated into global markets, and thus faced fewer 'green' trade requirements; and mining was concentrated in the Andes (and oil in the Amazon), where those historically excluded from socio-economic opportunities live, so the polity was more prone to conflict, regardless of pollution. In short, mining interacted with much more complex political economy conditions in Peru.

The contention, therefore, is that an even stronger policy agency, combining political willingness and technocratic muscle, would have been needed for effective institutional change in La Oroya. On the contrary, there was capture, disregard and incompetence on the part of political and policy elites. Frail reform attempts faced the negative feedback of chronic state failure and a development field still dominated by market fundamentalism. Institutional legacy and political economy opportunity made things less difficult for reformers of environmental rules in Chuquicamata than in La Oroya, but well-rooted and contingent conditions were not determining factors for the policy paths adopted and the development outcomes achieved from the early i 990 s onwards. State institutional endowments, in particular, are the outcome of social construction and can therefore be 'endogenised' 
by new societal action. Leadership becomes key; the cultural values of those in a position to influence, central.

\section{Spanish and Portuguese abstracts}

Spanish abstract. ¿Por qué y cómo las sociedades transforman las reglas medioambientales del desarrollo económico, o fracasan en hacerlo? Este artículo compara las experiencias de Chile y Perú en la regulación de las actividades de fundidoras de metales entre 1990 y 2010 . La contaminación del aire de parte de las fundidoras en Chuquicamata y La Oroya, desarrollos mineros emblemáticos de ambos países, no generaron protestas nacionales desestabilizadoras. Sin embargo, pese a la ausencia de un fuerte descontento por la contaminación, las reglas medioambientales para la minería pudieron ser mejoradas como resultado del trabajo de redes de activistas y a través canales institucionales altamente idiosincráticos. El análisis muestra que los emprendedores de políticas públicas en Chuquicamata se fortalecieron gracias a un ambiente institucional nacional que favoreció la autonomía burocrática, mientras que una acción paralela en La Oroya fue frenada por una economía política enmarcada en la debilidad estatal y el poco interés de las élites.

Spanish keywords: Chile, Perú, medio ambiente, desarrollo, minería, instituciones, emprendedores de políticas públicas

Portuguese abstract. Por que e como as sociedades transformam, ou deixam de transformar, as regras ambientais de desenvolvimento econômico? Este artigo compara as experiências do Chile e do Peru na regulamentação das atividades metalúrgicas entre os anos de 1990 e 2010 . A poluição atmosférica causada por metalúrgicas em Chuquicamata e La Oroya - sendo estes dois exemplos emblemáticos do setor de mineração de seus respectivos países - não culminaram em protestos nacionais desestabilizantes. Não obstante, apesar da falta de pressão pública causada pela insatisfação com a poluição, as regras ambientais para mineração ainda poderiam ser melhoradas como resultado do ativismo em redes políticas, e através de vias institucionais altamente personalizadas. As análises demonstram que as políticas de empreendedorismo para Chuquicamata foram fortalecidas por um ambiente institucional nacional que favorecia a autonomia burocrática, enquanto que em La Oroya foi inibida pela política econômica de enfraquecimento do Estado e desinteresse da elite.

Portuguese keywords: Chile, Peru, meio ambiente, desenvolvimento, mineração, instituições, empreendedores de políticas 